Published in final edited form as:

Clin Sci (Lond). 2015 July 1; 129(1): 81-92. doi:10.1042/CS20140776.

\title{
HYPOTENSIVE AND SYMPATHOINHIBITORY RESPONSES TO SELECTIVE CENTRAL AT2 RECEPTOR STIMULATION IN SPONTANEOUSLY HYPERTENSIVE RATS
}

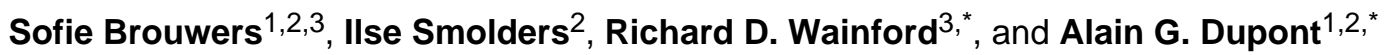 \\ ${ }^{1}$ Department of Pharmacology and Cardiovascular Center, Universitair Ziekenhuis Brussel, \\ Laarbeeklaan 101, 1090 Brussels, Belgium \\ 2Department of Pharmaceutical Chemistry, Drug Analysis and Drug Information (FASC), Center \\ for Neurosciences C4N, Vrije Universiteit Brussel, Laarbeeklaan 103, 1090 Brussels, Belgium \\ ${ }^{3}$ Department of Pharmacology and Experimental Therapeutics and the Whitaker Cardiovascular \\ Institute, Boston University School of Medicine, 700 Albany Street, Boston, MA 02118, USA
}

\section{Abstract}

The type 2 angiotensin $\left(\mathrm{AT}_{2}\right)$ receptor has been suggested to counterbalance the type 1 angiotensin $\left(\mathrm{AT}_{1}\right)$ receptor in the central regulation of blood pressure and sympathetic tone. We here investigated the blood pressure responses to stimulation of central $\mathrm{AT}_{2}$ receptors by the selective agonist Compound 21 in conscious SHR and normotensive WKY rats. We also assessed the impact on norepinephrine plasma levels, autonomic function, spontaneous baroreflex sensitivity, and the possible involvement of the nitric oxide-pathway and the $\mathrm{AT}_{1}$ receptor.

Chronic intracerebroventricular Compound 21 infusion lowered blood pressure and norepinephrine plasma levels in both rat strains. The nighttime hypotensive effect was greater in SHR compared to WKY. Compound 21 improved spontaneous baroreflex sensitivity more in SHR than in WKY. These effects were abolished by co-administration of $\mathrm{AT}_{2}$ receptor antagonist PD123319 or nitric oxide-synthase inhibitor L-NAME. Central $\mathrm{AT}_{1}$ receptor blockade did not enhance the hypotensive response to Compound 21.

Chronic selective stimulation of central $\mathrm{AT}_{2}$ receptors lowers blood pressure through sympathoinhibition, and improves spontaneous baroreflex sensitivity more in SHR than in WKY. These responses appear to require a functioning central nitric oxide-pathway, but are not modified by central $\mathrm{AT}_{1}$ receptor blockade.

Collectively, the data demonstrate specific beneficial effects of stimulation of central $\mathrm{AT}_{2}$ receptors in hypertension associated with increased sympathetic tone and suggest that central $\mathrm{AT}_{2}$

Correspondence to Sofie Brouwers, MD, Department of Pharmacology, Vrije Universiteit Brussel, Laarbeeklaan 103, B-1090Brussels, Belgium. Tel: +3224776432; fax: +3224776431; Sofie.Brouwers@ vub.ac.be.

Wainford RD and Dupont AG are joint last authors, they contributed equally to the manuscript.

Author contribution

SB co-designed the study protocols, performed experiments, analysed data, wrote the manuscript and obtained funding. IS, RDW and AGD initiated the study project, obtained the necessary funding, co-designed the study protocols, supervised the analysis and coauthored and edited the manuscript. 
receptors may represent a potential new therapeutic target for the treatment of neurogenic hypertension.

\section{Keywords}

Angiotensin II Type 2 Receptor; Compound 21; blood pressure; hypertension; central nervous system; Angiotensin II Type 1 Receptor

\section{Introduction}

Angiotensin II (AngII), the key player in the renin-angiotensin-system (RAS), mediates its effects mainly via the type $1\left(\mathrm{AT}_{1} \mathrm{R}\right)$ and type 2 angiotensin receptor $\left(\mathrm{AT}_{2} \mathrm{R}\right)$ [1]. $\mathrm{AT}_{1} \mathrm{R}$ are widely distributed throughout the body and mediate the classical cardiovascular effects of AngII, such as vasoconstriction, sodium retention, promotion of inflammatory responses, vascular smooth muscle cell proliferation and cardiac hypertrophy [1]. Current evidence suggests that the $\mathrm{AT}_{2} \mathrm{R}$ plays a counter-regulatory role opposing the $\mathrm{AT}_{1} \mathrm{R}$-mediated actions by promoting vasodilation, natriuresis and anti-inflammatory, anti-proliferative and antifibrotic responses [2]. Activation of the so-called protective arm of the RAS through stimulation of the $\mathrm{AT}_{2} \mathrm{R}$ has shown therapeutic potential in protecting against myocardial and brain injury [3]. Although $\mathrm{AT}_{2} \mathrm{R}$ stimulation can cause vasodilation ex vivo, peripheral $\mathrm{AT}_{2} \mathrm{R}$ stimulation does not translate into a significant antihypertensive effect in vivo, probably due to the dominating $\mathrm{AT}_{1} \mathrm{R}$ mediated vasoconstrictive tone [4].

The key role of the brain RAS, and in particular of the $\mathrm{AT}_{1} \mathrm{R}$, in the regulation of blood pressure and sympathetic tone is well established [5,6]. It is well known that brain AngII, acting through $\mathrm{AT}_{1} \mathrm{R}$, increases mean arterial pressure (MAP) and sympathetic nerve activity, but the possible role(s) of the central $\mathrm{AT}_{2} \mathrm{R}$ in cardiovascular regulation remains incompletely understood. Recent evidence suggests that the $\mathrm{AT}_{2} \mathrm{R}$ may also have a role in blood pressure regulation through sympatho-modulation [7,8]. Early investigations showed that intracerebroventricular (icv) injection of AngII evoked a larger increase in blood pressure in $\mathrm{AT}_{2} \mathrm{R}$ knockout mice compared to wild type mice, linking the central $\mathrm{AT}_{2} \mathrm{R}$ to blood pressure regulation and suggesting a counter-regulatory role for brain $\mathrm{AT}_{2} \mathrm{R}[9,10]$. In addition, overexpression of $\mathrm{AT}_{2} \mathrm{R}$ in the rostral ventrolateral medulla (RVLM), a primary brainstem nucleus related to the control of sympathetic outflow, reduced blood pressure and urinary norepinephrine (NE) excretion in normal Sprague-Dawley rats [11].

The availability of the non-peptide $\mathrm{AT}_{2} \mathrm{R}$ agonist Compound 21 (C21) [12,13] offers the possibility to selectively and specifically investigate $\mathrm{AT}_{2} \mathrm{R}$-mediated effects. $\mathrm{C} 21$ was reported to have cardio-, cerebro- and nephroprotective as well as anti-inflammatory effects. Its effect on vascular tone is complex and depends on experimental conditions [13]. We are aware of only one previous study, in conscious normotensive Sprague-Dawley rats, using central administration of $\mathrm{C} 21$ to investigate the effect of selective brain $\mathrm{AT}_{2} \mathrm{R}$ stimulation on blood pressure [14]. Central infusion of C21 in this rat strain decreased blood pressure and nighttime urinary NE excretion, suggesting a central inhibitory influence of C21 on sympathetic outflow [14]. In previous studies in our lab we were unable to detect direct blood pressure lowering effects following intravenous bolus injection or infusion of different 
doses of $\mathrm{C} 21$, even during $\mathrm{AT}_{1} \mathrm{R}$ blockade [15], indicating a lack of consistent blood pressure lowering effect after peripheral $\mathrm{C} 21$ administration. Currently, it is unknown whether central $\mathrm{AT}_{2} \mathrm{R}$ stimulation decreases blood pressure and sympathetic tone in the hypertensive setting. In the present study, we first aimed to confirm that in vivo chronic central stimulation of $\mathrm{AT}_{2} \mathrm{R}$ by $\mathrm{C} 21$ reduces blood pressure in Wistar Kyoto rats (WKY), another normotensive rat strain. Our main objective was to investigate the responses evoked by chronic icv infusion of C21 in Spontaneously Hypertensive Rats (SHR), a model of neurogenic hypertension. We also explored the potential mechanism(s) underlying the impact of $\mathrm{C} 21$ on blood pressure by investigating the effects of $\mathrm{C} 21$ on autonomic function and spontaneous baroreflex sensitivity (SBRS). As nitric oxide (NO) generated within the central nervous system (CNS) is known to interact with the brain RAS, including the $\mathrm{AT}_{2} \mathrm{R}$, to modulate the sympathetic nerve activity and blood pressure, we also determined the possible role of the NO-pathway in the responses evoked by central $\mathrm{AT}_{2} \mathrm{R}$ activation by $\mathrm{C} 21$ [6,8,16-20].

\section{Methods}

Animals

Male WKY and SHR rats (Charles River Laboratories, USA), 14 weeks of age, were housed individually in a temperature (range $68-79^{\circ} \mathrm{F}$ ) and humidity-controlled (range 30-70\%) facility under a 12-h light/dark cycle, maintained on normal rat diet with free access to tap water. All procedures were performed in accordance with the National Institutes of Health Guide for the Care and Use of Laboratory Animals and were approved by Boston University School of Medicine Institutional Animal Care and Use Committee.

\section{Surgical Procedures}

Telemetry Probe Implantation: A radiotelemetry device (PA-C40, DSI, MN, USA) was implanted into the abdominal aorta via the left femoral artery under ketamine anaesthesia (30 mg/kg intraperitoneally (ip) ketamine; $3 \mathrm{mg} / \mathrm{kg}$ ip xylazine).

Icv cannula and osmotic minipump placement: Following telemetry implantation and surgical recovery (5-7 days) animals were anaesthetized (30 $\mathrm{mg} / \mathrm{kg}$ ip ketamine in combination with $3 \mathrm{mg} / \mathrm{kg}$ ip xylazine) and stereotaxically implanted with a stainless steel cannula into the right lateral cerebral ventricle (Plastics One, VA, USA), which was connected via silastic tubing to an osmotic minipump (model 2004; Durect Corporation, CA, USA) for icv infusion [21].

\section{Experimental protocols}

Responses to icv infusion of the selective $\mathrm{AT}_{2} \mathrm{R}$ agonist $\mathrm{C} 21$ were assessed in WKY and SHR. Following completion of all surgical procedures and surgical recovery (5-7days) baseline blood pressure was recorded by telemetry on scheduled sampling 10-s every 10min interval over a 7-day period, in WKY and SHR. The mean of these values for every 24hour period was calculated to obtain a mean value for every day of the protocol. For the daytime and nighttime measurements, the mean values for respectively the 12-hour light cycle and dark cycle were calculated. In order to compare different treatments, changes in 
MAP were calculated as the change in blood pressure compared to day 7 of the baseline period. After 7 consecutive days of baseline measurements in animals receiving an icv saline vehicle infusion, rats were randomly assigned ( $\mathrm{n}=6-8$ per group) into treatment groups. WKY were followed up for an additional 7-day treatment period and SHR for a 14-day treatment period as their blood pressure continued to increase over the whole 14-day period in contrast with WKY. All compounds were dissolved in isotonic saline and infused icv at a rate of $0.25 \mu \mathrm{l} / \mathrm{h}$. Comparisons between WKY and SHR were done on the same treatment days. The 500ng dose of $\mathrm{C} 21$ was selected based on a previous study showing a hypotensive response in normotensive Sprague-Dawley rats [14]. In addition, lower doses were also investigated in order to detect the minimal effective dose of 20ng C21. Co-infusion treatments with $\mathrm{AT}_{1} \mathrm{R}$-blocker losartan $(10 \mu \mathrm{g} / \mathrm{h})$ and NO-synthase inhibitor L-NAME $(50 \mu \mathrm{g} / \mathrm{h})$ were given through the same osmotic minipump. The protocol is given in Figure S1 (see Online Supplement). Treatment groups and their doses are depicted in Table 1.

Spontaneous baroreceptor reflex sensitivity (SBRS) was calculated using the sequence method [22]. This was done during the baseline period on day 2 and 7 for WKY and SHR, and during the icv treatment period on day 9 and 14 for WKY, and on day 9, 14 and 21 for SHR (HemoLab Software Ver. 16.0). A time-dependent analysis was done. Radiotelemetry data were collected, stored, and analyzed using Dataquest A.R.T. 4.33 software (DSI, MN, USA). In order to further investigate possible changes in autonomic nervous system activity evoked by C21-infusion, acute systemic atropine and propranolol challenges were performed. Following a 30-minute continuous measurement of baseline heart rate (HR) and MAP via radiotelemetry ip bolus atropine $(1 \mathrm{mg} / \mathrm{kg})$ or propranolol $(2 \mathrm{mg} / \mathrm{kg})$ was administered and peak changes in HR and MAP were recorded. These studies were conducted for WKY on day 14, for SHR on day 21.

In certain groups, at the end of the protocol (day 15 for WKY, day 22 for SHR) plasma was collected and stored for subsequent measurement of plasma norepinephrine (NE) concentrations. After conscious decapitation, trunk blood was collected in EDTA tubes, immediately centrifuged for 15 minutes at $1000 \times \mathrm{g}$ at $4^{\circ} \mathrm{C}$ and the supernatant was stored at $-80^{\circ} \mathrm{C}$. The harvesting was done in the morning at the same time point for all animals, synchronized with the previous SBRS measurements.

In the saline-vehicle control experiments and the experiments involving losartan infusion, after measurement of baseline water intake for 30 minutes, animals received an icv injection of angiotensin II (100ng) and the dipsogenic response was recorded over 30 minutes [23] to confirm the blockade of the central $\mathrm{AT}_{1} \mathrm{R}$.

After completing the above-described protocol, rats from the saline-vehicle control group and the $\mathrm{C} 21(20 \mathrm{ng} / \mathrm{h})$ group were housed in individual metabolic cages for a $24 \mathrm{~h}$ period (model 18cv, Fenco, Cataumet, MA, USA) with external food containers and water bottles, for WKY on day 14, for SHR on day 21. Metabolic cages were equipped with a double-fine mesh screen that allowed separation of food and faeces contamination from urine that was collected in vials that contained a layer of mineral oil to prevent urine evaporation. Measurements were made for food and water intake, and urine output during a $24 \mathrm{~h}$ period enabling calculation of sodium and water balance [24]. 
Plasma NE concentration was determined by ELISA (IBL, MN, USA). For all groups, the ELISA was performed in duplicate and a mean of the results was taken. The plasma samples were not pooled from animals, each sample is from 1 individual rat. Urinary sodium content was determined by flame photometry (model 943; Instrumentation Laboratories, MA, USA) and urinary osmolality was measured by vapour pressure osmometer (Vapro 5500, Wescor Inc., Logan, UT, USA). Free water clearance and 24h sodium excretion were calculated. Urinary sodium excretion (meq/24h) equals $24 \mathrm{~h}$ urine output $(\mathrm{ml})$ times urinary sodium concentration (meq/liter). Free water clearance (CH20) was calculated as a difference between the rate of urine volume $(\mathrm{ml})$ per $24 \mathrm{~h}$ and the osmolar clearance [24].

\section{Drugs}

Losartan, PD123319 and Angiotensin II were purchased from Sigma-Aldrich Co. (St. Louis, USA). L-NAME was purchased from Santa Cruz Biotechnology (Dallas, USA). C21 was provided by Vicore Pharma AB (Göteborg, Sweden). Doses were selected based on previous studies $[14,25,26]$.

\section{Statistical Analysis}

Data are expressed as mean \pm SEM. Data were analyzed using Student's t-tests, ANOVA and appropriate post hoc analyses. Differences occurring between treatment groups (e.g., C21 vs. control) were assessed by a two-way repeated measures ANOVA, followed by a Bonferroni post hoc test, to compare variations among the groups. Alpha was set at 0.05 . All calculations and graphs were obtained by using GraphPad Prism 4.03 (GraphPad Software Inc., San Diego, CA, USA).

\section{Results}

\section{$\mathrm{AT}_{2} \mathrm{R}$-mediated blood pressure and heart rate responses to icv $\mathrm{C} 21$}

WKY-Mean blood1 pressure and heart rate values (average over 24 hours) in WKY during the 7-day period of baseline measurements were $110 \pm 2 \mathrm{mmHg}$ and $360 \pm 4 \mathrm{bpm}$, these values remain constant. In the control group, during saline vehicle infusion over the 14-day study period, these values remained constant (Figure 1A and S2A).

Icv infusion of C21 during the 7-day treatment period at doses of $20 \mathrm{ng} / \mathrm{h}$ and $500 \mathrm{ng} / \mathrm{h}$ significantly lowered MAP by $-6.1 \pm 0.6$ and $-5.6 \pm 0.9 \mathrm{mmHg}$ compared to pretreatment at day 7 , and by $-6.8 \pm 0.7$ and $-6.3 \pm 0.5 \mathrm{mmHg}$ compared to saline-vehicle control group values at day $14(\mathrm{p}<0.05)$ (Figure 1A and Figure S3A). Lower doses of C21 ((2ng/h), (10ng/h)) did not alter MAP (Figure S3B).

Co-infusion of the $\mathrm{AT}_{2} \mathrm{R}$ antagonist PD123319 with $\mathrm{C} 21$ (20ng/h and 500ng/h) abolished the $\mathrm{C} 21$ evoked decrease in MAP (Figure 1A, S2A and S3A). PD123319 alone did not significantly change MAP (Figure S3C). HR did not change in any of these experimental groups (Figure S4A).

SHR-MAP increased progressively in SHR over the 7-day baseline period from day 0 onwards, with however some variation of the magnitude of the blood pressure increase 
between individual animals. We therefore considered in each group the average MAP measured at day 7 , i.e. immediately before infusion of test compounds versus saline vehicle, as a baseline. These baseline values for MAP and HR were $153 \pm 5 \mathrm{mmHg}$ and $355 \pm 4 \mathrm{bpm}$. The MAP increased from baseline progressively during the 14-day period in the saline vehicle control SHR by $+11.7 \pm 2.9 \mathrm{mmHg}$ to a value of $164 \pm 5 \mathrm{mmHg}(\mathrm{p}<0.01)$ (Figure $2 \mathrm{~A}$ and S5A).

Icv infusion of $\mathrm{C} 21$ for a 14 -day period at doses of $20 \mathrm{ng} / \mathrm{h}$ and $500 \mathrm{ng} / \mathrm{h}$ prevented this spontaneous blood pressure increase and reduced MAP from baseline values recorded on day 7 of saline infusion by $-6.1 \pm 1.6$ and $-3.8 \pm 1.5 \mathrm{mmHg}$ respectively. After 7 days of C21infusion, at day 14 of the protocol, the difference in MAP compared to the saline-vehicle control group was $-9.0 \pm 1.7$ and $-5.3 \pm 1.4 \mathrm{mmHg}$ respectively and the decrease in MAP was highly significant after 14 days of $\mathrm{C} 21$-infusion, at day 21 of the protocol, $-18.0 \pm 2.0$ and $-15.5 \pm 1.6 \mathrm{mmHg}$ respectively $(\mathrm{p}<0.001)$ (Figure $2 \mathrm{~A}$ and $\mathrm{S} 6 \mathrm{~A})$. The hypotensive effect of icv $\mathrm{C} 21$ infusion was abolished by PD123319 co-infusion ( $<<0.001$ vs $\mathrm{C} 21$ alone) (Figure 2A, S5A and S6A). PD123319 alone did not significantly change MAP compared to the saline control group (Figure S6C). No significant HR changes were observed in these SHR experiments (Figure S7A). The magnitude of the hypotensive response (24h average) after 7-days infusion of C21 (20ng/h) (compared to saline for the same period) tended to be slightly greater in SHR than in WKY, but the difference did not reach statistical significance. However, after 14 days infusion in SHR, the blood pressure lowering effect was more pronounced and significantly greater than observed after 7 days in both, WKY and SHR $(\mathrm{p}<0.001)$.

Nighttime versus daytime blood pressure-We performed an additional analysis of the day versus nighttime blood pressures. In both strains, nighttime blood pressure was significantly higher than daytime blood pressure both under saline infusion (Night vs. Day MAP (mmHg): WKY $+5.0 \pm 0.3 ;$ SHR $+5.8 \pm 0.5 ; \mathrm{p}<0.001)$ and during C21-infusion $(20 \mathrm{ng} / \mathrm{h})$ (Night vs. Day MAP (mmHg): WKY $+4.9 \pm 0.3$; SHR $+5.4 \pm 0.5 ; \mathrm{p}<0.001$ ). The magnitude of the blood pressure reduction induced by 7-day $\mathrm{C} 21$ infusion was similar in the two strains during daytime ( 21 evoked peak change in MAP $(\mathrm{mmHg})$ : WKY $-5.5 \pm 0.6$, SHR $-5.4 \pm 1.5$ ). However, during nighttime, icv $\mathrm{C} 21$ for 7 days reduced blood pressure significantly more in SHR than in WKY from baseline values (C21 evoked peak change in nighttime MAP (mmHg): WKY $-8.2 \pm 0.8$ vs. SHR $-12.6 \pm 1.9$; $\mathrm{p}<0.01$ ). In SHR, the magnitude of the nighttime hypotensive responses to icv $\mathrm{C} 21$ for 7 or 14 days was significantly greater than during daytime both after $7(\mathrm{p}<0.05)$ and $14(\mathrm{p}<0.001)$ days; a similar but statistically not significant trend was seen in WKY (Table 2).

\section{Effect of icv C21-infusion on $\mathrm{AT}_{2} \mathrm{R}$-mediated changes in autonomic and renal function}

Norepinephrine plasma levels-In control icv vehicle saline-infused rats, plasma NE levels were significantly lower in WKY $(217.0 \pm 19.4 \mathrm{pg} / \mathrm{mL})$ than in SHR (317.2 $\pm 14.7 \mathrm{pg} / \mathrm{mL} ; \mathrm{p}<0.05)$. C21-infusion $(20 \mathrm{ng} / \mathrm{h})$ significantly decreased NE plasma concentration versus saline infusion in WKY to $180.1 \pm 13.6 \mathrm{pg} / \mathrm{mL}(\mathrm{p}<0.05)$ and in SHR to $262.9 \pm 19.8 \mathrm{pg} / \mathrm{mL}(\mathrm{p}<0.05)$. In both strains, PD alone had no effect on NE $(\mathrm{n}=3$, data not 
shown) but abolished the decreases in NE plasma concentration evoked by icv C21-infusion (Figure 3).

Autonomic function-C21-infusion had no effect on the increase in HR evoked by ip bolus atropine in either WKY (vehicle $+119.7 \pm 11.0$ vs C21 $+114.0 \pm 12.5 \mathrm{bpm}$; NS) or in SHR (vehicle $+102.2 \pm 11.3$ vs C $21+107.1 \pm 5.4 \mathrm{bpm}$; NS). The bradycardic response to ip bolus propranolol was significantly attenuated in the C21-treated animals (WKY: vehicle $-49.7 \pm 3.0$ vs $\mathrm{C} 21-25.0 \pm 3.2$ bpm; $<<0.05$; SHR: vehicle $-68.2 \pm 2.4$ vs C $21-36.3 \pm 4.1 \mathrm{bpm}$; p $<0.05$ ). PD123319 co-infusion abolished this effect of C21 (Figure 4).

SBRS-SBRS, as measured on day 2 and day 7 of the baseline period under saline vehicle infusion, was significantly impaired in the SHR compared to WKY (SBRS (ms $/ \mathrm{mmHg}$ ) saline infusion: WKY D2 2.6 \pm 0.3 , D7 2.5 \pm 0.4 vs SHR D2 2.0 \pm 0.1 , D7 1.8 \pm 0.2 ; both $\mathrm{p}<0.05$ ) (Figure $5 \mathrm{~A}$ and $5 \mathrm{E}$ ).

C21-infusion (20ng/h) immediately and significantly increased SBRS in both strains; this effect was maintained throughout the infusion period (SBRS (ms/mmHg) C21 20ng/h infusion; WKY D9 3.6 \pm 0.3 , D14 3.7 \pm 0.4 ; both $\mathrm{p}<0.01$ vs baseline; SHR D9 3.2 \pm 0.2 , D14 $3.4 \pm 0.2$, D21 3.7 \pm 0.1 ; all $\mathrm{p}<0.01$ vs baseline) (Figure 5A and 5E). The improvement in SBRS on D14 was more pronounced in SHR than in WKY (84 vs 46\%; $\mathrm{p}<0.001$ ). A higher concentration C21-infusion (500ng/h) also increased significantly SBRS (SBRS (ms/mmHg) C21 $500 \mathrm{ng} / \mathrm{h}$ infusion: WKY D9 3.9 \pm 0.4 , D14 3.8 \pm 0.5 ; both p<0.01; SHR D9 3.0 \pm 0.6 , D14 3.0 \pm 0.5 , D21 3.2 \pm 0.5 ; all p<0.01) (Figure S8). The C21-induced increase in SBRS was abolished by co-infusion of PD123319 in both strains (Figure 5B and 5F), whereas infusion of PD123319 alone had no significant effect on SBRS.

Fluid and Electrolyte Homeostasis-C21-infusion did not alter sodium balance or free water clearance in WKY or SHR. We observed no difference in sodium excretion (WKY: vehicle $-0.67 \pm 0.2$ vs $\mathrm{C} 21-0.77 \pm 0.2 \mathrm{mEq} /$ day; NS; SHR: vehicle $-0.54 \pm 0.1$ vs $\mathrm{C} 21$ $-0.47 \pm 0.1$; NS) or free water clearance (WKY: vehicle $-24.3 \pm 4.5$ vs C21 $-25.3 \pm 4.2 \mathrm{ml} /$ day; NS; SHR: vehicle $-26.5 \pm 4.2$ vs C21 $-28.1 \pm 4.2$; NS) following C21-infusion (Figure S9).

\section{Impact of icv $A T_{1} R$ and $N O$ on $A_{2} R$-mediated physiological effects}

WKY - Co-infusion of the $\mathrm{AT}_{1} \mathrm{R}$ antagonist losartan, in a dose $(10 \mu \mathrm{g} / \mathrm{h})$ that abolished the dipsogenic response to icv injection of AngII seen in control WKY and SHR (Figure S10), with $\mathrm{C} 21$ (20 and 500ng/h) did not further enhance the MAP lowering effect seen with C21 alone (20 and 500ng/h) (Figure 1B, S2B and S3D).

L-NAME infusion alone significantly increased MAP from baseline values by $+11.8 \pm 1.7$ $\mathrm{mmHg},(\mathrm{p}<0.001)$ (Figure 1C and S2C) and decreased HR from baseline by $-24.4 \pm 4.7 \mathrm{bpm}$ $(\mathrm{p}<0.05)$ (Figure S4B) without altering SBRS (Figure 5D). Co-infusion of L-NAME and $\mathrm{C} 21$ abolished the hypotensive effect of $\mathrm{C} 21$, evoking an increase in MAP from baseline values by $+8.4 \pm 0.9 \mathrm{mmHg}$ ( $<<0.01$ vs $\mathrm{C} 21$ alone) (Figure $1 \mathrm{C}$ and $\mathrm{S} 2 \mathrm{C}$ ) and also abolished C21-induced increases in SBRS (Figure 5C). 
SHR-As in the WKY co-infusion of the $\mathrm{AT}_{1} \mathrm{R}$ antagonist losartan $(10 \mu \mathrm{g} / \mathrm{h})$ with $\mathrm{C} 21(20$ and 500ng/h) did not further enhance the MAP lowering effect seen with $\mathrm{C} 21$ alone (20 and 500ng/h) in SHR (Figure 2B, S5B and S6B).

L-NAME infusion alone significantly increased MAP from baseline by $+38.7 \pm 2.5 \mathrm{mmHg}$ $(\mathrm{p}<0.05)$ (Figure 2C and S5C) and tended to reduce HR. L-NAME $(50 \mu \mathrm{g} / \mathrm{h})$ co-infusion blocked the effect of $\mathrm{C} 21(20 \mathrm{ng} / \mathrm{h})$ and increased MAP from baseline by $+37.1 \pm 3.2 \mathrm{mmHg}$ ( $\mathrm{p}<0.05$ vs $\mathrm{C} 21$ alone) (Figure $2 \mathrm{C}$ and $\mathrm{S} 5 \mathrm{C}$ ) and significantly reduced HR from baseline by $-16.0 \pm 2.8 \mathrm{bpm}(\mathrm{p}<0.05)$ (Figure S7B). Although MAP was still significantly different $(\mathrm{p}<0.05)$ from day 10 until day 13 between the groups $\mathrm{C} 21$ 20ng+L-NAME and L-NAME alone, MAP and HR with co-infusion of C21+L-NAME were not different from the corresponding values with L-NAME infusion alone at D21. C21-induced increases in SBRS were again abolished by co-infusion of L-NAME (Figure 5G); icv infusion of L-NAME alone did not alter SBRS (Figure 5H).

\section{Discussion}

The major novel finding of the present study is that central chronic stimulation of the $\mathrm{AT}_{2}$ receptor by the selective non-peptide $\mathrm{AT}_{2} \mathrm{R}$ agonist Compound 21 evoked a sustained decrease in blood pressure not only in normotensive but also in spontaneously hypertensive rats in vivo, and that this hypotensive response is associated with sympatho-inhibition and increased spontaneous baroreflex sensitivity. These data further demonstrate there is a differential response to $\mathrm{C} 21$ between the SHR and WKY rat in multiple parameters.

It is well established that brain AngII induces tonic sympatho-excitatory effects resulting in blood pressure increases through stimulation of central $\mathrm{AT}_{1} \mathrm{R}$. However, the possible role of brain $\mathrm{AT}_{2} \mathrm{R}$ in blood pressure control is less well understood, although current evidence suggests that $\mathrm{AT}_{2} \mathrm{R}$ in the RVLM may mediate sympatho-inhibitory effects [6,11]. In the current experiments, we observed that chronic icv infusion of $\mathrm{C} 21$, at doses of 20 or 500 $\mathrm{ng} / \mathrm{h}$, consistently lowered blood pressure and plasma NE concentrations in normotensive WKY. Recent in vitro experiments suggested that $\mathrm{C} 21$ may, like most other drugs, induce unspecific effects in concentrations above $1 \mu \mathrm{M}$ [27]. However, the central blood pressure lowering and sympatholytic effects observed in the present study were observed at much lower concentrations of C21 $(0.04 \mu \mathrm{mol} / \mathrm{L})$. Moreover, these effects were both abolished by concomitant infusion of PD123319 administered in a dose known to selectively block the $\mathrm{AT}_{2} \mathrm{R}[28]$ and not reaching the high concentration at which it would be expected to also block the $\mathrm{AT}_{1} \mathrm{R}$, confirming that these responses were probably $\mathrm{AT}_{2} \mathrm{R}$-mediated.

The results obtained in WKY validate and extend earlier findings conducted in male Sprague-Dawley rats [14] that $\mathrm{AT}_{2} \mathrm{R}$ activation lowers blood pressure in normotensive rat phenotypes. These authors also reported a reduction in nighttime urinary NE excretion, supporting our finding of a sympatho-inhibitory response to chronic central $\mathrm{AT}_{2} \mathrm{R}$ stimulation. It is of interest to note that, whereas the effects of $\mathrm{C} 21$ were abolished by PD123319, indicating that exogenous stimulation of brain $\mathrm{AT}_{2} \mathrm{R}$ in normotensive rats results in sympatho-inhibition, chronic infusion of PD123319 alone had no effect on MAP nor NE 
levels, suggesting that endogenous activation of brain $\mathrm{AT}_{2} \mathrm{R}$ does not appear to contribute significantly to the control of blood pressure and sympathetic tone under basal conditions.

The most important novel observations of the present study relate to the experiments conducted in SHR. To our knowledge this is the first study investigating responses to chronic central $\mathrm{AT}_{2} \mathrm{R}$ stimulation th.rough icv infusion of $\mathrm{C} 21$ in an in vivo conscious animal model of hypertension. As expected, and in line with the available literature [29], blood pressure progressively increased by almost $12 \mathrm{mmHg}$ in the control SHR followed for a 21-day period of saline-vehicle infusion. Icv infusion of $\mathrm{C} 21$ from day 8 till day 21 completely prevented this progressive blood pressure increase and further lowered MAP to below the baseline levels on day 7 . The magnitude of this response was significantly greater than the response seen in either SHR or WKY after 7 days of infusion. As expected, nighttime blood pressure was significantly higher than daytime blood pressure in both strains. Interestingly, whereas the magnitude of the blood pressure reduction induced by $\mathrm{C} 21$ was similar in the two strains during daytime, in SHR, the nighttime hypotensive response to $\mathrm{C} 21$ was significantly greater than during daytime. Moreover, during nighttime, icv C21 for 7 days reduced blood pressure significantly more in SHR than in WKY, suggesting that brain $\mathrm{AT}_{2} \mathrm{R}$ may be involved in blood pressure control in particular during nighttime in SHR.

The marked hypotensive response in a model of hypertension induced by specific and selective stimulation of brain $\mathrm{AT}_{2} \mathrm{R}$ observed in the present study is in sharp contrast to the lack of effect on blood pressure by stimulation of peripheral $\mathrm{AT}_{2} \mathrm{R}$ [4]. Indeed, although evidence of $\mathrm{AT}_{2} \mathrm{R}$ mediated vasodilation is available ex vivo, in vivo studies on the possible blood pressure lowering effect of peripheral $\mathrm{AT}_{2} \mathrm{R}$ stimulation in hypertensive animal models have yielded conflicting results, and hypotensive responses were either not detectable or only during co-administration of an $\mathrm{AT}_{1}$ antagonist at low dose [30,31]. This lack of significant antihypertensive effect has resulted in the conclusion that non-peptide $\mathrm{AT}_{2} \mathrm{R}$ agonists would not become a new class of antihypertensive drugs. The present study, however, suggests that centrally acting $\mathrm{AT}_{2} \mathrm{R}$ agonists may have significant blood pressure lowering effects provided they can cross the blood-brain barrier.

Our observation that $\mathrm{C} 21$ mediated stimulation of central $\mathrm{AT}_{2} \mathrm{R}$ prevented the spontaneous blood pressure increase in SHR is in line with the recent demonstration by Blanch et al that increased expression of $\mathrm{AT}_{2} \mathrm{R}$ in the solitary-vagal complex, a brainstem region important in the control of blood pressure, attenuates the increase in arterial pressure observed in a rat model with 2-kidney 1-clip renovascular hypertension [32].

In line with previous evidence indicating that SHR have a higher sympathetic tone compared to normotensive control rats [33], baseline plasma NE concentrations were higher in SHR compared to WKY. As observed in the WKY, the hypotensive response to infusion of $\mathrm{C} 21$ in SHR was also associated with a significant reduction of the plasma concentrations of NE, measured as a surrogate marker of sympathetic tone. Again, both responses were abolished by concomitant infusion of PD123319, confirming the direct involvement of the $\mathrm{AT}_{2} \mathrm{R}$ in these responses. As in the WKY experiments, infusion of PD123319 alone had no significant effect on MAP or plasma NE concentrations. These results suggest that 
exogenous stimulation of brain $\mathrm{AT}_{2} \mathrm{R}$ prevents the progressive increase in blood pressure in SHR through a sympatho-inhibitory action.

In order to further investigate possible changes in autonomic nervous system activity evoked by C21-infusion, acute systemic atropine and propranolol challenges were performed in both, SHR and WKY. In both strains, the peak tachycardic responses to an ip bolus injection atropine were unaltered by icv $\mathrm{C} 21$-infusion, suggesting that exogenous $\mathrm{AT}_{2} \mathrm{R}$ stimulation did not alter parasympathetic tone. However, the peak bradycardic responses to propranolol were significantly reduced by C21-infusion, in SHR as well as in WKY, and PD123319 abolished this effect. This is in line with the hypothesis of a $\mathrm{C} 21$ induced $\mathrm{AT}_{2} \mathrm{R}$-mediated decrease in central sympathetic outflow, without a relevant effect on parasympathetic activity.

Another important finding of our study is that exogenous brain $\mathrm{AT}_{2} \mathrm{R}$ stimulation improved spontaneous baroreceptor reflex sensitivity in both WKY and SHR. Baroreflex dysfunction is an important hallmark of hypertension [34] that is closely related to sympathetic hyperactivity and activation of the circulating and local RAS [35]. Reduction in baroreflex sensitivity is considered an independent marker of the risk of mortality and major adverse cardiovascular events in hypertensive patients [36]. SHR are known to exhibit impaired baroreceptor reflex function [37]. Accordingly, in the present study, SBRS measurements were impaired at baseline and in control experiments with saline-vehicle infusion in SHR compared to WKY. Icv infusion of C21 improved the SBRS in both strains rapidly after the start of the infusion and this was maintained throughout the whole experiment, but the effect in SHR was significantly greater than in WKY. This C21 induced improvement in spontaneous baroreceptor reflex sensitivity was abolished by concomitant infusion of the selective $\mathrm{AT}_{2} \mathrm{R}$ antagonist PD123319 confirming that this effect is mediated through this receptor. It is tempting to speculate that the prevention of the progression of hypertension in SHR induced by central $\mathrm{AT}_{2} \mathrm{R}$ stimulation observed in the present study is, in part, related to this restoration of baroreceptor function. These results also confirm the recent observation that increased expression of $\mathrm{AT}_{2} \mathrm{R}$ in the solitary-vagal complex restores baroreflex function and sympathetic modulation of arterial pressure to normal values in rats with 2-kidney 1-clip renovascular hypertension, another rat model characterized by baroreceptor impairment and increased sympathetic tone [32].

The possible in vivo role of peripheral $\mathrm{AT}_{2} \mathrm{R}$ stimulation in renal sodium handling has been extensively studied [2]. $\mathrm{AT}_{2} \mathrm{R}$ stimulation by intravenous $\mathrm{C} 21$-infusion has been reported to promote natriuresis by a direct effect on tubular function [38-40]. On the other hand, in $\mathrm{AT}_{2}$-null mice, no changes in natriuresis were seen, except under additional AngII-infusion, where an antinatriuretic hypersensitivity was observed [9]. Regarding a possible role for central $\mathrm{AT}_{2} \mathrm{R}$, a transient increase in urine excretion was reported in normotensive rats with overexpression of $\mathrm{AT}_{2} \mathrm{R}$ in the RVLM [11]. We therefore also investigated whether chronic icv infusion would have an effect on sodium balance and on free water clearance, but we could not detect any effect of C21 on fluid and electrolyte handling in WKY nor SHR. This negative result is not necessarily in contradiction with the observation of Gao et al, as the increase in urine excretion that they observed was transient and short lasting compared with the prolonged overexpression of $\mathrm{RVLM} \mathrm{AT}_{2} \mathrm{R}$ that they generated, and the measurements of 
sodium balance and free water clearance performed in the present study were made at the end of the C21 treatment periods (after 7 days for WKY and 14 days for SHR). Further, the same group did not report the effect of C21-infusion on renal parameters in their subsequent study in Sprague-Dawley rats [14].

The interplay between NO and different components of the RAS, including the $\mathrm{AT}_{2} \mathrm{R}$ has been previously reported $[16,41,42]$. We therefore also evaluated whether the responses to icv C21 can be affected by central inhibition of NO-synthase. In line with the previous observation in normotensive Sprague-Dawley rats [14], we demonstrated that in both WKY and SHR the depressor responses to central $\mathrm{AT}_{2} \mathrm{R}$ stimulation are blocked by icv infusion of the NO-synthase-inhibitor L-NAME, although we cannot completely exclude that the lack of detectable hypotensive response to C21 under L-NAME infusion might at least in part be related to the very pronounced blood pressure increase induced by L-NAME itself.

Further, although the hypotensive response to C21 was abolished after 14-days of L-NAME infusion, it was only partly reversed by L-NAME during the first days of co-infusion. Therefore other possible mechanisms might also be involved such as direct crosstalk or downregulation of $\mathrm{AT}_{1}$ receptors. $\mathrm{AT}_{2} \mathrm{R}$ have been shown upon activation to heterodimerize with $\mathrm{AT}_{1} \mathrm{R}$, reducing their cell surface [43] expression. $\mathrm{AT}_{2} \mathrm{R}-\mathrm{AT}_{1} \mathrm{R}$ heterodimerization may also affect intracellular $\mathrm{AT}_{1} \mathrm{R}$ signalling [44,45] resulting in a functional inhibition of the latter and adding to the complexity of $\mathrm{AT}_{2} \mathrm{R}$ physiopathology. Nevertheless, as $\mathrm{AT}_{2} \mathrm{R}$ antagonists like PD123319 have also been reported to also antagonize Mas receptor mediated effects [46], other effects not directly linked to $\mathrm{AT}_{2} \mathrm{R}$ stimulation, or an interaction with the Mas-related G-protein-coupled receptor cannot be entirely excluded. However, we also showed that co-infusion of L-NAME abolished the improvement in baroreceptor sensitivity induced by central $\mathrm{AT}_{2} \mathrm{R}$ stimulation by $\mathrm{C} 21$, indicating that these effects of $\mathrm{AT}_{2} \mathrm{R}$ stimulation require a functional central NO pathway. These results are in line with a recent study in anaesthetized Wistar rats suggesting a facilitatory role for $\mathrm{AT}_{2} \mathrm{R}$ in high pressure baroreflex regulation which is NO-dependent [16]. Icv infusion of L-NAME alone significantly increased MAP and reduced HR (the latter probably through activation of the high pressure baroreflex), both in WKY and SHR, supporting current evidence of the important role for endogenous NO in the brain in the central control of blood pressure [42]. However, no differences were detected when L-NAME infused alone was compared with combined icv infusion of L-NAME with C21.

We also addressed the possibility of a contribution of the $\mathrm{AT}_{1} \mathrm{R}$ in the central $\mathrm{AT}_{2} \mathrm{R}$ mediated responses in the present study based on the hypothesis that stimulation of both receptors could result in opposing responses. Peripheral $\mathrm{AT}_{1} \mathrm{R}$ blockade to functionally antagonize the $\mathrm{AT}_{1} \mathrm{R}$ has been required to unmask $\mathrm{AT}_{2} \mathrm{R}$-mediated vasodilation in $\mathrm{SHR}$ [30,31]. Therefore we also investigated the centrally mediated $\mathrm{C} 21$ responses when the counterbalancing actions of $\mathrm{AT}_{1} \mathrm{R}$ were blocked with losartan given at a dose known to have no hypotensive effect by itself after central administration [47] but sufficient to block the dipsogenic effect of exogenous AngII. In contrast with the findings reported for the peripheral vasculature, the hypotensive response to chronic icv $\mathrm{C} 21$-infusion is not enhanced by additional central $\mathrm{AT}_{1} \mathrm{R}$ blockade, in either WKY or in SHR. In our studies the response 
to $\mathrm{C} 21$ co-infusion at two different doses $(20 \mathrm{ng} / \mathrm{h}$ and $500 \mathrm{ng} / \mathrm{h})$ with or without losartan did not differ.

In conclusion, the results of the present study provide the first evidence that chronic selective stimulation of the central $\mathrm{AT}_{2}$ receptor by the selective non-peptide $\mathrm{AT}_{2} \mathrm{R}$ agonist Compound 21 induces a vasodepressor response in hypertensive rats, preventing the progressive blood pressure increase normally observed in this animal model. This hypotensive response is associated with lowered NE plasma levels, suggesting a decrease in sympathetic tone, and improvement of the SBRS. The improvement in baroreceptor reflex sensitivity and the hypotensive effect during nighttime is more pronounced in SHR than in WKY. In addition this study shows that these brain $\mathrm{AT}_{2} \mathrm{R}$-mediated responses require a functioning central NO-pathway, but are independent of the presence of functioning central $\mathrm{AT}_{1} \mathrm{R}$. The modulation of blood pressure regulation and correction of impaired sympathoregulation that is potentially achievable by balancing the actions of central inhibitory $\mathrm{AT}_{2} \mathrm{R}$ versus excitatory $\mathrm{AT}_{1} \mathrm{R}$ effects through central $\mathrm{AT}_{2} \mathrm{R}$ stimulation could open new therapeutic opportunities for diseases characterized by sympatho-excitation. However, it should be stressed that although many other studies also reported beneficial responses to $\mathrm{AT}_{2} \mathrm{R}$ stimulation, the opposite has also been reported in pathological conditions or ageing animals and depending on the location of the receptor (endothelium or smooth muscle cell), as well as its capacity to heterodimerize with $\mathrm{AT}_{1}$ receptors [48].

\section{Supplementary Material}

Refer to Web version on PubMed Central for supplementary material.

\section{Acknowledgments}

SB's and RW's collaboration has been supported by the International Society Hypertension New Investigator Committee. SB is a member of the International Society of Hypertension Corporate Liaison Committee and the Networking and Mentorship Working Group of the International Society of Hypertension New Investigator Committee. RDW is member of the International Society of Hypertension Scientific Council and the Recruitment Working Group of the International Society of Hypertension New Investigator Committee.

Funding

This research was supported by a grant from the Research council of the Vrije Universiteit Brussel and NIH R01HL107330, K02HL112718 to RDW. SB is holder of research fellowship and travel grant of the Flemish Research Fund and a grant from the Horlait-Dapsens Foundation.

\section{References}

1. de Gasparo M, Catt KJ, Inagami T, Wright JW, Unger T. International union of pharmacology. XXIII The angiotensin II receptors. Pharmacol Rev. 2000; 52:415-472. [PubMed: 10977869]

2. Padia SH, Carey RM. AT2 receptors: beneficial counter-regulatory role in cardiovascular and renal function. Pflugers Arch. 2013; 465:99-110. [PubMed: 22949090]

3. Namsolleck P, Recarti C, Foulquier S, Steckelings UM, Unger T. AT(2)receptor and tissue injury: therapeutic implications. Curr Hypertens Rep. 2014; 16:416. [PubMed: 24414230]

4. Steckelings UM, Paulis L, Namsolleck P, Unger T. AT2 receptor agonists: hypertension and beyond. Curr Opin Nephrol Hypertens. 2012; 21:142-146. [PubMed: 22257799]

5. Guyenet PG. The sympathetic control of blood pressure. Nat Rev Neurosci. 2006; 7:335-346. [PubMed: 16760914] 
6. Dupont AG, Brouwers S. Brain angiotensin peptides regulate sympathetic tone and blood pressure. J Hypertens. 2010; 28:1599-1610. [PubMed: 20502352]

7. Li Y, Li XH, Yuan H. Angiotensin II type-2 receptor-specific effects on the cardiovascular system. Cardiovasc Diagn Ther. 2012; 2:56-62. [PubMed: 24282697]

8. Gao L, Zucker IH. AT2 Receptor Signaling and Sympathetic Regulation. Curr Opin Pharmacol. 2011; 11:124-130. [PubMed: 21159555]

9. Siragy HM, Inagami T, Ichiki T, Carey RM. Sustained hypersensitivity to angiotensin II and its mechanism in mice lacking the subtype-2(AT2) angiotensin receptor. Proc Natl Acad Sci USA. 1999; 96:6506-6510. [PubMed: 10339618]

10. Li Z, Iwai M, Wu L, Shiuchi T, Jinno T, Cui TX, Horiuchi M. Role of AT2 receptor in the brain in regulation of blood pressure and water intake. Am J Physiol: Heart Circ Physiol. 2003; 284:116121.

11. Gao L, Wang W, Wang W, Li H, Sumners C, Zucker IH. Effects of angiotensin type 2 receptor overexpression in the rostral ventrolateral medulla on blood pressure and urine excretion in normal rats. Hypertension. 2008; 51:21-527.

12. Wan Y, Wallinder C, Plouffe B, Beaudry H, Mahalingam AK, Wu X, Johansson B, Holm M, Botoros M, Karlen A, Pettersson A, Nyberg F, Fandriks L, Gallo-Payet N, Hallberg A, Alterman M. Design, synthesis, and biological evaluation of the first selective nonpeptide AT2 receptor agonist. J Med Chem. 2004; 47:5995-6008. [PubMed: 15537354]

13. Steckelings UM, Larhed M, Hallberg A, Widdop RE, Jones ES, Wallinder C, Namsolleck P, Dahlöf B, Unger T. Non-peptide AT2-receptor agonists. Curr Opin Pharmacol. 2011; 11:187-192. [PubMed: 21167778]

14. Gao J, Zhang H, Le KD, Chao J, Gao L. Activation of central angiotensin type 2 receptors suppresses norepinephrine excretion and blood pressure in conscious rats. Am J Hypertens. 2011; 24:724-730. [PubMed: 21394088]

15. Brouwers S, Smolders I, Massie A, Dupont AG. Angiotensin II type 2 receptor-mediated and oxide-dependent renal vasodilator response to compound 21 unmasked by angiotensin-converting enzyme inhibition in spontaneously hypertensive rats in vivo. Hypertension. 2013; 62:920-926. [PubMed: 24041944]

16. Abdulla MH, Johns EJ. Nitric oxide impacts on angiotensin AT2 receptor modulation of highpressure baroreflex control of renal sympathetic nerve activity in anaesthetized rats. Acta Physiol. 2014; 210:832-844.

17. Schelman WR, Kurth JL, Berdeaux RL, Norby SW, Weyhenmeyer JA. Angiotensin II type-2(AT2) receptor-mediated inhibition of NMDA receptor signalling in neuronal cells. Brain Res Mol Brain Res. 1997; 48:197-205. [PubMed: 9332716]

18. Sosa-Canache B, Cierco M, Gutierrez CI, Israel A. Role of bradykinins and nitric oxide in the AT2 receptor-mediated hypotension. J Hum Hypertens. 2000; 14:S40-S46. [PubMed: 10854080]

19. Qadri F, Carretero OA, Scicli AG. Centrally produced neuronal nitric oxide in the control of baroreceptor reflex sensitivity and blood pressure in normotensive and spontaneously hypertensive rats. Jpn J Pharmacol. 1999; 81:279-285. [PubMed: 10622216]

20. Patel KP, Li YF, Hirooka Y. Role of nitric oxide in central sympathetic outflow. Exp Biol Med. 2001; 226:814-824.

21. Kapusta DR, Pascale CL, Kuwabara JT, Wainford RD. Central nervous system Gai2-subunit proteins maintain salt resistance via a renal nerve-dependent sympathoinhibitory pathway. Hypertension. 2013; 61:368-375. [PubMed: 23213191]

22. Xia H, Feng Y, Obr TD, Hickman PJ, Lazartigues E. Angiotensin II type 1 receptor-mediated reduction of angiotensin-converting enzyme 2 activity in the brain impairs baroreflex function in hypertensive mice. Hypertension. 2009; 53:210-216. [PubMed: 19124678]

23. Vento PJ, Daniels D. Repeated administration of angiotensin II reduces its dipsogenic effect without affecting saline intake. Exp Physiol. 2010; 95:736-745. [PubMed: 20228119]

24. Wei SG, Yu Y, Zhang ZH, Felder RB. Angiotensin II upregulates hypothalamic AT1 receptor expression in rats via the mitogen-activated protein kinase pathway. Am J Physiol: Heart Circ Physiol. 2009; 296:1425-1433. 
25. Wainford RD, Kapusta DR. Hypothalamic paraventricular nucleus G alpha q subunit protein pathways mediate vasopressin dysregulation and fluid retention in salt-sensitive rats. Endocrinology. 2010; 151:5403-5414. [PubMed: 20861238]

26. Toney GM, Porter JP. Effects of blockade of AT1 and AT2 receptors in brain on the central angiotensin II pressor response in conscious spontaneously hypertensive rats. Neuropharmacology. 1993; 32:581-589. [PubMed: 8336821]

27. Verdonk K, Durik M, Abd-Alla N, Batenburg WW, van den Bogaerdt AJ, van Veghel R, Roks AJ, Danser AH, van Esch JH. Compound 21 induces vasorelaxation via an endothelium- and angiotensin II type 2 receptor-independent mechanism. Hypertension. 2012; 60:722-729. [PubMed: 22802221]

28. Bosnyak S, Jones ES, Christopoulos A, Aguilar MI, Thomas WG, Widdop RE. Relative affinity of angiotensin peptides and novel ligands at AT1 and AT2 receptors. Clin Sci. 2011; 121:297-303. [PubMed: 21542804]

29. Yamori, Y. The development of Spontaneously Hypertensive Rat (SHR) and of various spontaneous rat models, and their implications. In: de Jong, W., editor. Handbook of Hypertension. Vol. 4. Experimental and genetic models of hypertension. Elsevier; Amsterdam, New York, Oxford: 1984. p. 224-239.

30. Li XC, Widdop RE. AT2 receptor-mediated vasodilatation is unmasked by AT1 receptor blockade in conscious SHR. Br J Pharmacol. 2004; 142:821-30. [PubMed: 15197103]

31. Bosnyak S, Welungoda IK, Hallberg A, Alterman M, Widdop RE, Jones ES. Stimulation of angiotensin AT2 receptors by the non-peptide agonist, Compound 21, evokes vasodepressor effects in conscious spontaneously hypertensive rats. Br J Pharmacol. 2010; 159:709-716. [PubMed: 20128808]

32. Blanch GT, Freiria-Oliveira AH, Speretta GF, Carrera EJ, Li H, Speth RC, Colombari E, Sumners $\mathrm{C}$, Colombari DS. Increased expression of angiotensin II type 2 receptors in the solitary-vagal complex blunts renovascular hypertension. Hypertension. 2014; 64:777-783. [PubMed: 24958505]

33. Folkow B. Physiological aspects of primary hypertension. Physiol Rev. 1982; 62:347-504. [PubMed: 6461865]

34. Bristow JD, Honour AJ, Pickering GW, Sleight P, Smyth HS. Diminished baroreflex sensitivity in high blood pressure. Circulation. 1969; 39:48-54. [PubMed: 4302539]

35. Veerasingham SJ, Raizada MK. Brain renin-angiotensin system dysfunction in hypertension: recent advances and perspectives. Br J Pharmacol. 2003; 139:191-202. [PubMed: 12770924]

36. Ormezzano O, Cracowski JL, Quesada JL, Pierre H, Mallion JM, Baguet JP. EVAluation of the prognostic value of BARoreflex sensitivity in hypertensive patients: the EVABAR study. J Hypertens. 2008; 26:1373-1378. [PubMed: 18551013]

37. Ceroni A, Chaar LJ, Bombein RL, Michelini LC. Chronic absence of baroreceptor inputs prevents training-induced cardiovascular adjustments in normotensive and spontaneously hypertensive rats. Exp Physiol. 2009; 94:630-640. [PubMed: 19251981]

38. Danyel LA, Schmerler P, Paulis L, Unger T, Steckelings UM. Impact of AT2-receptor stimulation on vascular biology, kidney function, and blood pressure. Integr Blood Press Control. 2013; 6:153-161. [PubMed: 24379697]

39. Kemp BA, Howell NL, Gildea JJ, Keller SR, Padia SH, Carey RM. AT2 Receptor Activation Induces Natriuresis and Lowers Blood Pressure. Circ Res. 2014; 115:388-399. [PubMed: 24903104]

40. Hilliard LM, Chow CL, Mirabito KM, Steckelings UM, Unger T, Widdop RE, Denton KM. Angiotensin type 2 receptor stimulation increases renal function in female, but not male, spontaneously hypertensive rats. Hypertension. 2014; 64:378-83. [PubMed: 24842923]

41. Fernandez-Alfonso MS, Gonzalez C. Nitric oxide and the renin-angiotensin system. Is there a physiological interplay between the systems? J Hypertens. 1999; 17:1355-1361. [PubMed: 10526894]

42. Toda N, Ayajiki K, Okamura T. Control of systemic and pulmonary blood pressure by nitric oxide formed through neuronal nitric oxide synthase. J Hypertens. 2009; 27:1929-1940. [PubMed: 19587610] 
43. Yang J, Chen C, Ren H, Han Y, He D, Zhou L, Hopfer U, Jose PA, Zeng C. Angiotensin II AT(2) receptor decreases AT(1) receptor expression and function via nitric oxide/cGMP/Sp1 in renal proximal tubule cells from Wistar-Kyoto rats. J Hypertens. 2012; 30:1176-1184. [PubMed: 22504846]

44. Widdop RE, Matrougui K, Levy BI, Henrion D. AT2 receptor-mediated relaxation is preserved after long-term AT1 receptor blockade. Hypertension. 2002; 40:516-520. [PubMed: 12364356]

45. Savoia C, Touyz RM, Volpe M, Schiffrin EL. Angiotensin type 2 receptor in resistance arteries of type 2 diabetic hypertensive patients. Hypertension. 2007; 49:341-346. [PubMed: 17159079]

46. Villela D, Leonhardt J, Patel N, Joseph J, Kirsch S, Hallberg A, Unger T, Bader M, Santos RA, Sumners C, Steckelings UM. Angiotensin type 2 receptor (AT2R) and receptor Mas: a complex liaison. Clin Sci. 2015; 128:227-234. [PubMed: 25328009]

47. Kawano Y, Yoshida K, Matsuoka H, Omae T. Chronic effects of central and systemic administration of losartan on blood pressure and baroreceptor reflex in spontaneously hypertensive rats. Am J Hypertens. 1994; 7:536-542. [PubMed: 7917152]

48. Sevá Pessôa B, van der Lubbe N, Verdonk K, Roks AJ, Hoorn EJ, Danser AH. Key developments in renin-angiotensin-aldosterone system inhibition. Nat Rev Nephrol. 2013; 9:26-36. [PubMed: 23165302] 


\section{Clinical Perspectives}

Collectively, the data from our study support a role of the $\mathrm{AT}_{2} \mathrm{R}$ as an important element in the beneficial arm of the RAS. We provide the first evidence that chronic selective central $\mathrm{AT}_{2} \mathrm{R}$ stimulation attenuates hypertension and improves autonomic dysfunction and impaired baroreflex sensitivity in SHR. In contrast to peripheral $\mathrm{AT}_{2} \mathrm{R}$ receptors for which there is now abundant evidence that their stimulation does not result in consistent blood pressure lowering effects, the present study suggests that centrally acting $\mathrm{AT}_{2} \mathrm{R}$ agonists may have significant blood pressure lowering effects provided they can cross the blood-brain barrier. Further research into a better understanding of the location, age and disease-dependent roles of the $\mathrm{AT}_{2}$ receptor is warranted before $\mathrm{AT}_{2}$-receptor agonists can be brought to the clinic. 


\section{Summary Statement}

This in vivo study demonstrates that chronic selective central $\mathrm{AT}_{2} \mathrm{R}$ stimulation by $\mathrm{C} 21$ results in a NO-dependent hypotensive effect through sympatho-inhibition and improved spontaneous baroreflex sensitivity. These effects are more pronounced in spontaneously hypertensive rats compared to normotensive rats. 

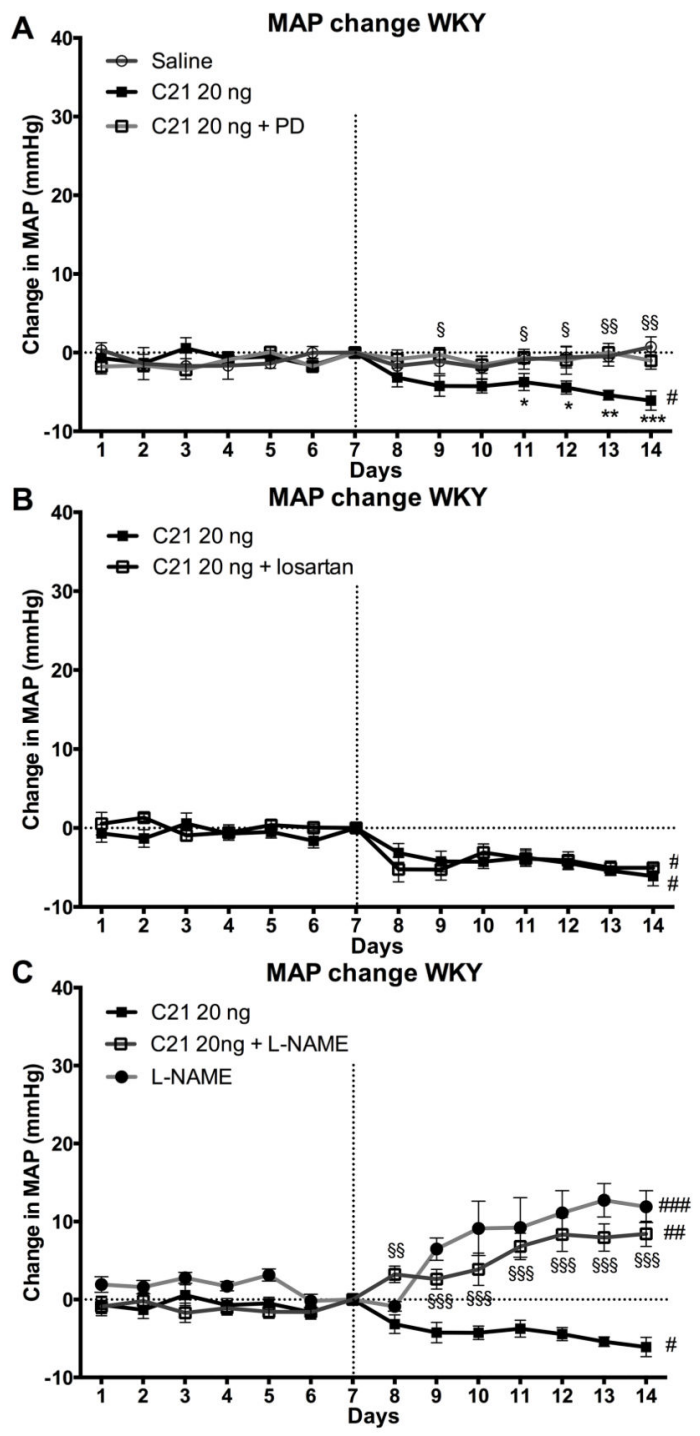

Fig. 1.

Change in mean arterial blood pressure (MAP) in Wistar Kyoto rats (WKY). Data are shown as mean \pm SEM ( $n=6-8$ per group). $\S \mathrm{P}<0.05, \S \S \mathrm{P}<0.01, \S \S \S \mathrm{P}<0.001$ compared to $\mathrm{C} 2120 \mathrm{ng}$; $* \mathrm{P}<0.05, * * \mathrm{P}<0.01, * * * \mathrm{P}<0.001$ compared to saline-vehicle control (multiple comparisons 2-way ANOVA). \#P<0.05, \#\#P<0.01; \#\#\#P<0.001 compared to baseline values on day 7 (ANOVA for repeated measures). 
A
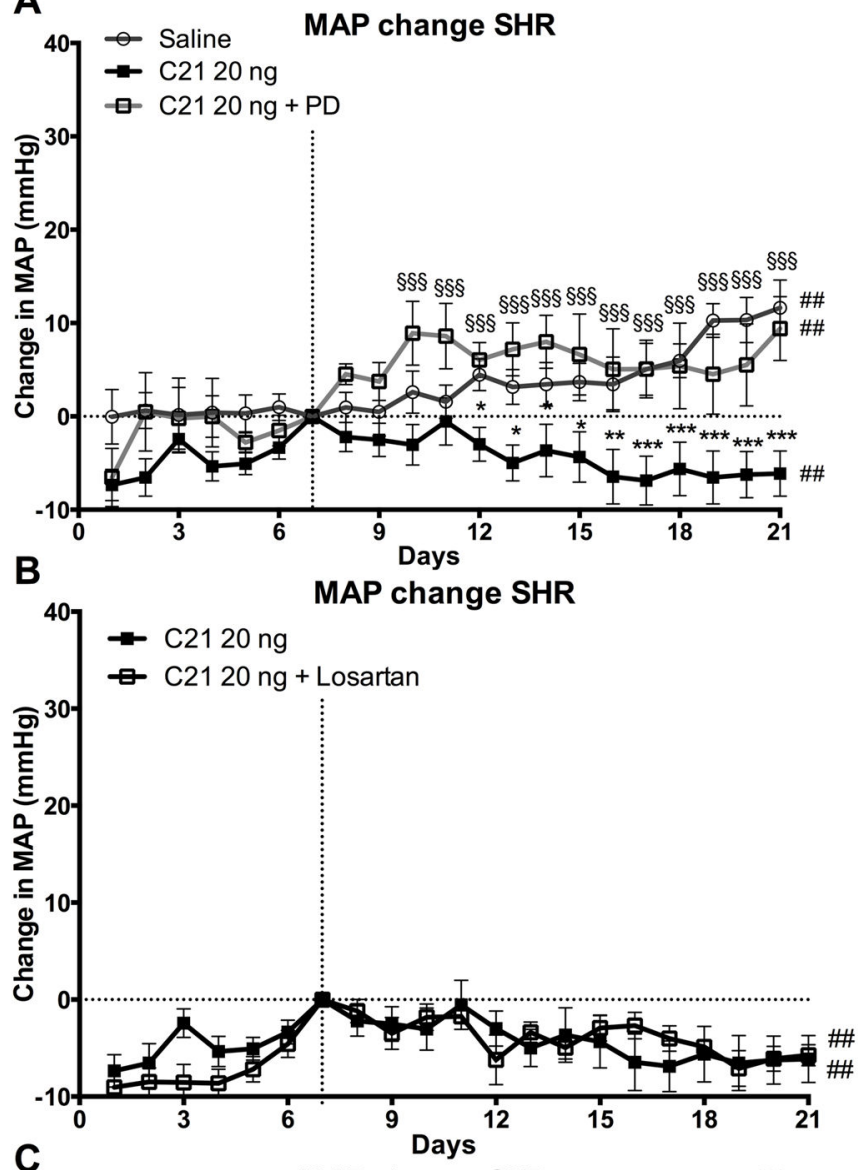

C

MAP change SHR

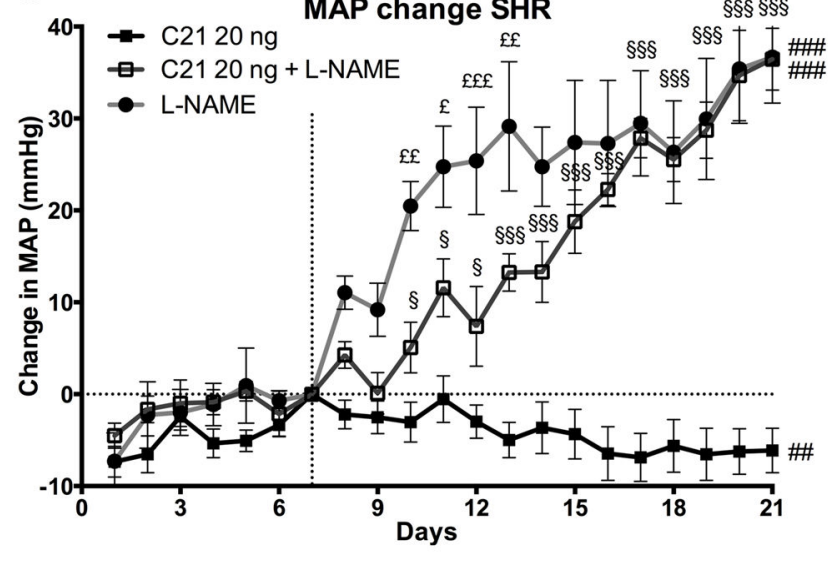

Fig. 2.

Change in mean arterial blood pressure (MAP) in Spontaneously Hypertensive rats (SHR). Data are shown as mean \pm SEM ( $\mathrm{n}=6-8$ per group). $\S \mathrm{P}<0.05$, $\S \S \mathrm{P}<0.001$ compared to $\mathrm{C} 21$ 20ng; $* \mathrm{P}<0.05, * * \mathrm{P}<0.01,{ }^{*} * * \mathrm{P}<0.001$ compared to saline-vehicle control; $£ \mathrm{P}<0.05, £$ $£ \mathrm{P}<0.01, £ £ £ \mathrm{P}<0.001$ compared to C21 20ng + L-NAME (multiple comparisons 2-way ANOVA). \#\#P<0.01, \#\#\#P<0.001 compared to baseline values on day 7 (ANOVA for repeated measures). 


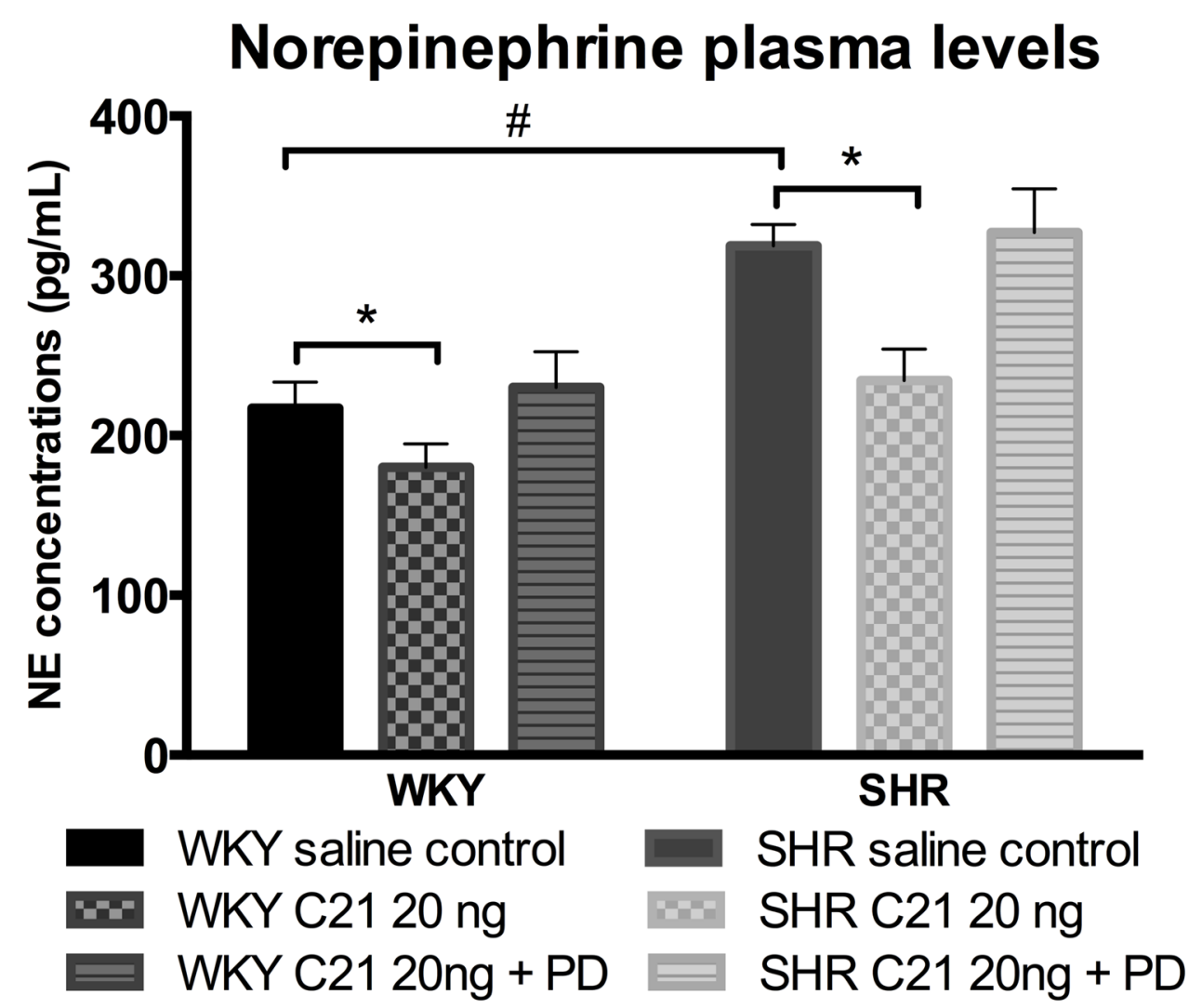

Fig. 3.

Norepinephrine (NE) plasma levels in Wistar Kyoto rats (WKY) and Spontaneously Hypertensive rats (SHR). Data are shown as mean \pm SEM ( $n=6-8$ per group). $* \mathrm{P}<0.05$ compared to corresponding saline control. \# $\mathrm{P}<0.05$ comparing saline control in SHR to corresponding saline control in WKY. 

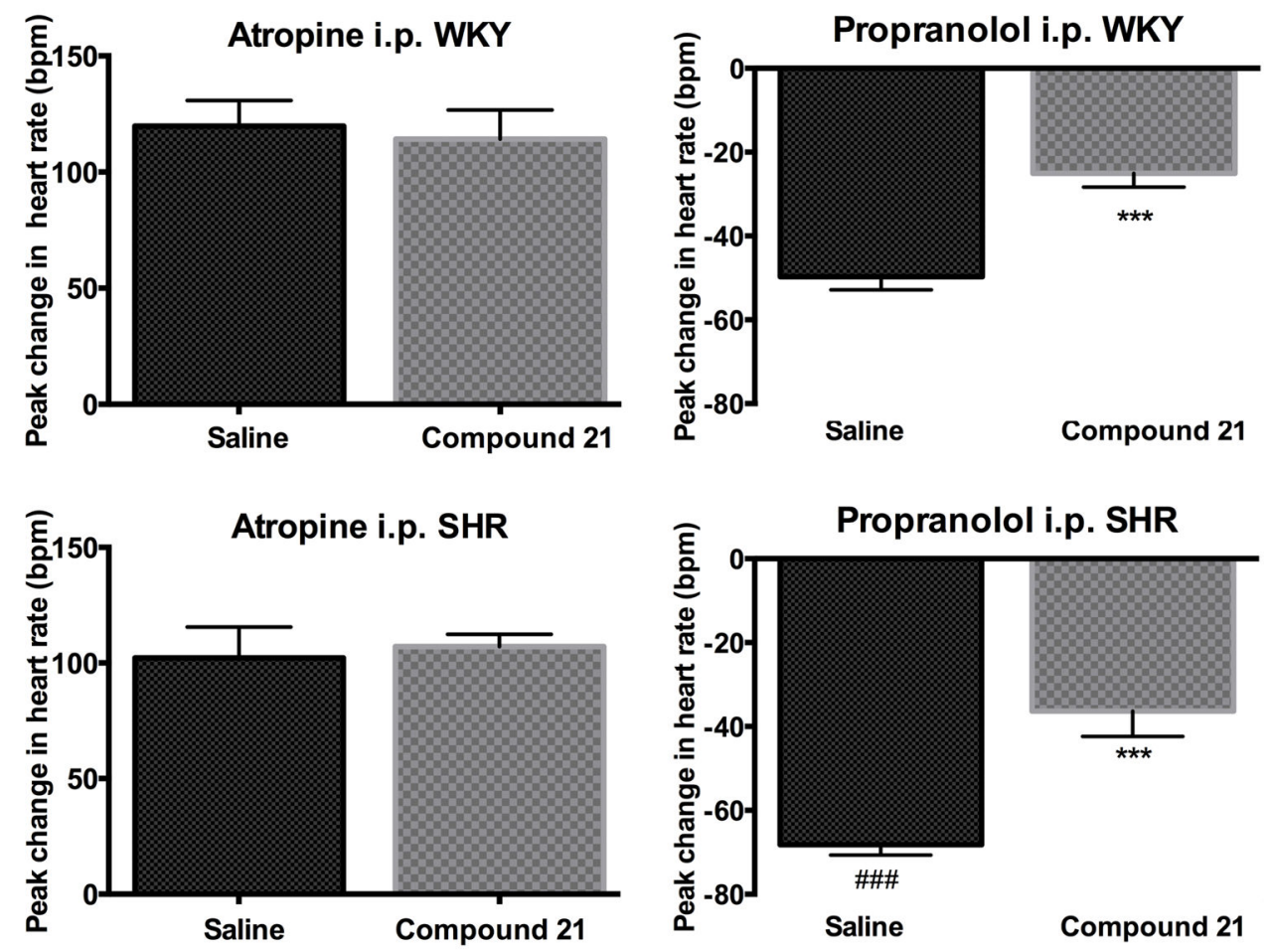

Fig. 4.

Peak change in heart rate (HR) in Wistar Kyoto rats (WKY) (upper panels) and Spontaneously Hypertensive rats (SHR) (lower panels) after ip injection of atropine and propranolol at the end of C21-infusion. Data are shown as mean \pm SEM ( $n=6-8$ per group). $* * * \mathrm{P}<0.001$ compared to corresponding saline control. \#\#\#P<0.001 comparing saline control in SHR to corresponding saline control in WKY on D7. 
A

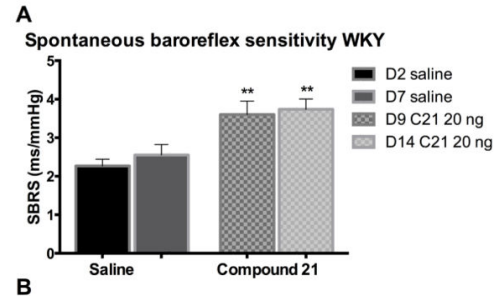

B

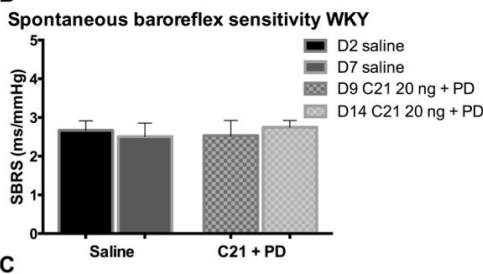

C

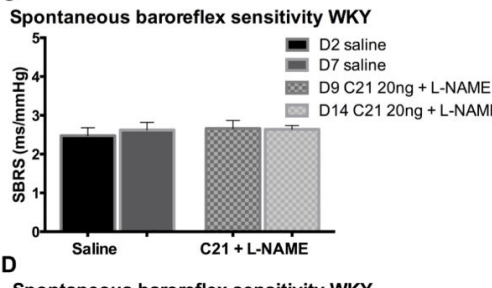

D

Spontaneous baroreflex sensitivity WKY

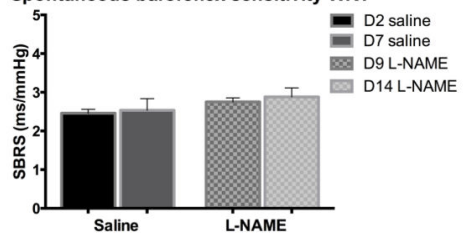

Spontaneous baroreflex sensitivity SHR

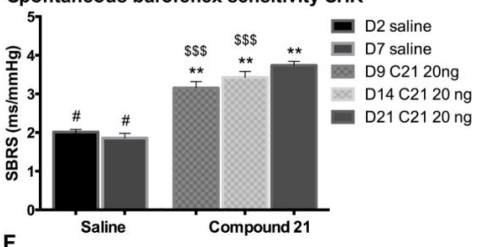

F

Spontaneous baroreflex sensitivity SHR

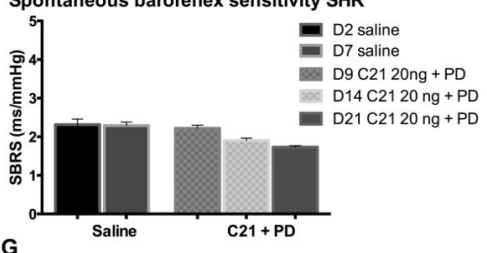

Spontaneous baroreflex sensitivity SHR

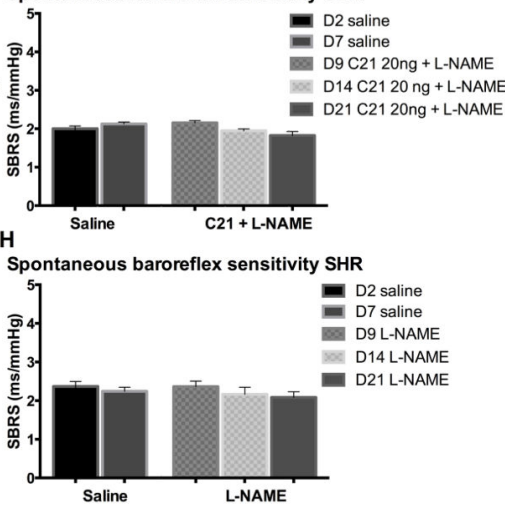

Fig. 5.

Spontaneous baroreflex sensitivity (SBRS) in Wistar Kyoto rats (WKY) (panels A,B,C,D) and Spontaneously Hypertensive rats (SHR) (panels E, F, G, H). Data are shown as mean \pm SEM ( $\mathrm{n}=6-8$ per group). ${ }^{*} \mathrm{P}<0.01$ compared to corresponding saline control, D2 vs D9, D7 vs D14, D7 vs D21. \#P $<0.05$ comparing saline control in SHR to corresponding saline control in WKY. \$\$P $<0.001$ comparing change in SBRS in SHR to corresponding change in WKY. 


\section{Table 1}

Overview of the treatment groups in WKY and SHR.

\begin{tabular}{|l|l|}
\hline WKY & SHR \\
\hline saline vehicle control & saline vehicle control \\
\hline C21 $(2 \mathrm{ng} / \mathrm{h})$ & \\
\hline C21 $(10 \mathrm{ng} / \mathrm{h})$ & \\
\hline C21 $(20 \mathrm{ng} / \mathrm{h})$ & C21 $(20 \mathrm{ng} / \mathrm{h})$ \\
\hline C21 $(500 \mathrm{ng} / \mathrm{h})$ & C21 $(500 \mathrm{ng} / \mathrm{h})$ \\
\hline C21 $(500 \mathrm{ng} / \mathrm{h})+$ PD123319 $(500 \mathrm{ng} / \mathrm{h})$ & C21 $(500 \mathrm{ng} / \mathrm{h})+$ PD123319 $(500 \mathrm{ng} / \mathrm{h})$ \\
\hline C21 $(20 \mathrm{ng} / \mathrm{h})+$ PD123319 $(20 \mathrm{ng} / \mathrm{h})$ & C21 $(20 \mathrm{ng} / \mathrm{h})+$ PD123319 $(20 \mathrm{ng} / \mathrm{h})$ \\
\hline PD123319 $(20 \mathrm{ng} / \mathrm{h})$ & PD123319 $(20 \mathrm{ng} / \mathrm{h})$ \\
\hline C21 $(500 \mathrm{ng} / \mathrm{h})+$ losartan $(10 \mu \mathrm{g} / \mathrm{h})$ & C21 $(500 \mathrm{ng} / \mathrm{h})+$ losartan $(10 \mu \mathrm{g} / \mathrm{h})$ \\
\hline C21 $(20 \mathrm{ng} / \mathrm{h})+$ losartan $(10 \mu \mathrm{g} / \mathrm{h})$ & C21 $(20 \mathrm{ng} / \mathrm{h})+$ losartan $(10 \mu \mathrm{\mu g} / \mathrm{h})$ \\
\hline C21 $(20 \mathrm{ng} / \mathrm{h})+\mathrm{L}-\mathrm{NAME}(50 \mu \mathrm{g} / \mathrm{h})$ & C21 $(20 \mathrm{ng} / \mathrm{h})+\mathrm{L}-\mathrm{NAME}(50 \mu \mathrm{g} / \mathrm{h})$ \\
\hline L-NAME $(50 \mu \mathrm{\mu} / \mathrm{h})$ & L-NAME $(50 \mu \mathrm{g} / \mathrm{h})$ \\
\hline
\end{tabular}




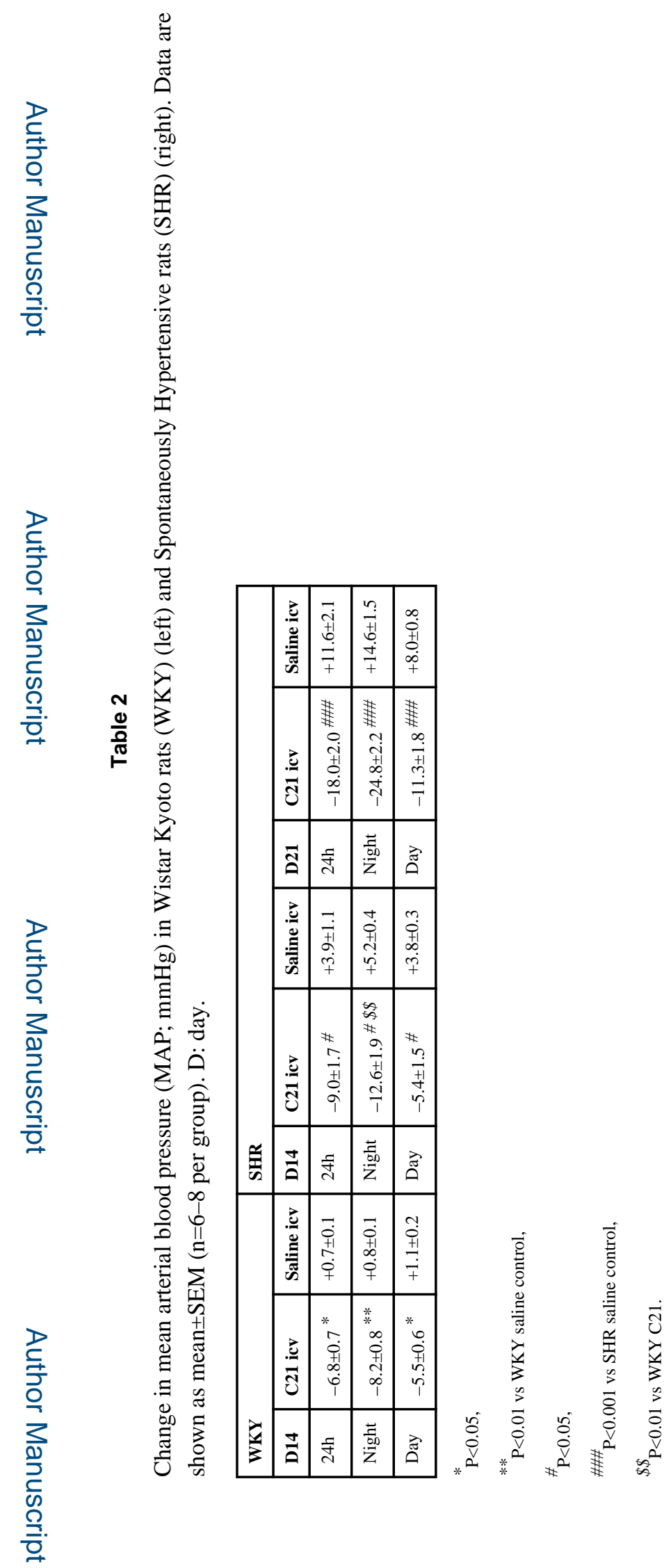

Clin Sci (Lond). Author manuscript; available in PMC 2016 July 01. 